\title{
Professor: artesão ou operário?
}

\section{Teacher: craftsman or worker?}

\section{Profesor: artesano o trabajador?}

Fabiane Maia Garcia Universidade Federal do Amazonas (Brasil) Leonel Elias Bene Universidade Púnguè - Extensão de Tete (Moçambique)

PARO, Vitor Henrique. Professor: artesão ou operário? São Paulo: Cortez, 2018.

O livro teve origem a partir de uma pesquisa realizada em uma escola municipal de ensino fundamental da cidade de São Paulo com professores(as) da escola básica. O livro analisa a singularidade da ação educativa escolar enquanto processo de trabalho, bem como investiga suas implicações para as políticas educacionais e para a administração da educação fundamental.

O livro é constituído por 141 páginas e é dividido em quatro capítulos. Se trata de uma obra autoral que se constrói a partir da ideia de que o professor, pelas especificidades do seu trabalho, não pode ser considerado um mero executor de políticas emanadas por outrem. Esse é um trabalho que envolve sujeitos que rejeitam a tônica presente no discurso neoliberal que remete o trabalho do professor a um simples serviço operário, ao validar a ideia da escola como empresa. Ao tomarmos como referência os indicadores que a Coordenação de Aperfeiçoamento de Pessoal de Nível Superior (CAPES, BRASIL, 2020) preconizam para as obras na área da Educação, percebe-se que a obra alcança facilmente os requisitos propostos para uma obra classificada como L1. O livro é produto de uma editora nacional que possui um comité editorial para a área de versão impressa. Nossa pretensão é indicar uma obra que reflete a vivacidade e as múltiplas faces com as quais o neoliberalismo vem permeando o trabalho docente ao buscar transformá-lo num trabalho operário colocando em perigo a existência do docente e sua essência como educador.

No capítulo primeiro, com o título "Educação enquanto atividade pedagógica", o autor apresenta um debate acerca da cultura como objeto da 
educação afirmando que o ato educativo promove uma apropriação e não há nenhuma transmissão de conhecimentos ou de qualquer outro elemento cultural. $\bigcirc$ educando se apodera do conhecimento sem que este deixe de pertencer ao educador. Desse modo, o livro desmascara a falsa ideia de que a ação educativa é a simples transmissão de conteúdos. Para o autor, a educação exige um saber técnico científico e sem este temos uma escola que não ensina. $\bigcirc$ diálogo e a democracia no contexto escolar se deparam com a ideologia do "não" que mina todo o esforço de tornar a escola democrática e impede que o aluno participe da relação pedagógica, uma tendência que reproduz adultos cuja relação mútua será baseada no autoritarismo desafiando qualquer moralismo social.

No segundo capítulo, "Educação enquanto processo de trabalho", o autor conceptualiza o trabalho na visão marxista como "uma atividade orientada a um fim", especificamente humana, pois só o homem tem a capacidade de estabelecer objetivos que o fazem agir. Paro chama a atenção ao levar-nos a pensar no trabalho manual e no trabalho intelectual com o intuito de evitarmos a valorização de um em detrimento do outro. Para o autor, a educação vai exercer um papel fundamental nesse sentido. A partir de Marx, entende 2 que tanto o educador quanto o educando são trabalhadores ao despender sua energia humana (força de trabalho) na realização do produto, já que a atividade é de ensino e aprendizado. Nesse sentido, não é errado exigir que a escola seja produtiva, desde que haja clareza da exigência do produto. $\bigcirc$ professor, diferentemente do operário, está diante de um objeto de trabalho singular porque não se trata de um objeto similar ao utilizado no processo de produção material, mas de um sujeito. Isso se revela fundamental quando o assunto são as políticas educacionais. $\bigcirc$ resultado da produção pedagógica, ao contrário da capitalista, é um produto imediatamente útil, relevante para o indivíduo e com um compromisso social com o produto.

No capítulo terceiro, "Quem 'trabalha' no processo pedagógico", recupera o conceito de trabalho de Marx que alude à uma compreensão de que tanto o educador como o educando são trabalhadores. Trata-se de um trabalho que está em discrepância com o modo de produção capitalista, em que o trabalhador não se preocupa com o destino da produção. Reconhece que os diferentes prêmios que são atribuídos aos professores se afiguram como uma forma de alienar o trabalho docente igualando-o ao trabalho forçado da produção capitalista. $\bigcirc$ autor rejeita a equiparação do professor ao proletário, 
pois o docente não produz mais-valia, ou seja, o excedente ao valor de sua força de trabalho que é apropriado pelo proprietário do capital, o Estado. Contudo, essa explicação não é válida quando se trata de professores das escolas privadas que têm de produzir para que os seus salários sejam pagos e gerar mais-valia para o proprietário da escola. $\bigcirc$ autor entende que há uma tendência de se colocar o professor como o único educador do aluno. Quando fracassa, é quase certo que seja culpabilizado, mesmo que a função educativa não dependa unicamente do professor.

No capítulo quarto, "conclusões" são tecidas considerações acerca do livro e da pesquisa realizada. $\bigcirc$ autor discorre uma crítica diante da onda neoliberal que visa à minimização do Estado e à descaracterização da escola como instância privilegiada de apropriação da cultura. Indivíduos do mundo dos negócios, e sem familiaridade com a educação e a escola, surgem como promotores de ideias visando a oferecer soluções aos problemas da gestão escolar. Assevera o autor que a relação pedagógica deve ser democrática e dialógica, pois envolve relações políticas de poder (tanto do aluno como do professor) e a escola tem de atender os interesses dos cidadãos em geral, não a interesses particulares, muito menos empresariais. $\bigcirc$ livro assevera o combate às iniciativas da razão mercantil e do amadorismo pedagógico que tanto têm contribuído para solapar as esperanças. Devemos considerar que o professor não é um operário, não apenas no sentido de que não produz mais-valia, mas porque seu trabalho não permite os constrangimentos do trabalho forçado, pois "na produção pedagógica, a degradação do trabalhador impede essa consecução, prejudicando não apenas o professor, mas também o aluno, frustrando assim, o trabalho da escola".

Esta obra pode ser pauta de estudo, análise e discussão tanto na graduação quanto na pós-graduação, pois apresenta uma linguagem simples, mas também útil como um caminho metodológico para os estudos de inspiração Marxista.

\section{Referências}

BRASIL. Ministério da Educação. Coordenação de Aperfeiçoamento de Pessoal de Nível Superior. Avaliação de livros: área 38 - Educação. Brasília: Capes, 2020 


\section{Profa. Dra. Fabiane Maia Garcia \\ Universidade Federal do Amazonas (Brasil) Departamento de Administração e Planejamento Faculdade de Educação Programa de Pós-Graduação em Educação} Linha de Pesquisa Educação, Políticas Públicas e Desenvolvimento Regional Orcid id: https:/ / orcid.org/0000-0003-0121-0416 E-mail: fgarciaead@hotmail.com Mestrando Leonel Elias Bene
Programa de Pós-Graduação em Educação
Universidade Federal do Amazonas (Brasil)
Universidade Púnguè - Extensão de Tete (Moçambique)
Linha de Pesquisa Educação, Políticas Públicas e Desenvolvimento Regional
Orcid id: https:/ / orcid.org/0000-0002-5293-8493
E-mail: leonel.bene@gmail.com
Recebida 29 maio 2020
Aceita 8 jun. 2020 Mestrando Leonel Elias Bene
Programa de Pós-Graduação em Educação
Universidade Federal do Amazonas (Brasil)
Universidade Púnguè - Extensão de Tete (Moçambique)
Linha de Pesquisa Educação, Políticas Públicas e Desenvolvimento Regional
Orcid id: https:/ / orcid.org/0000-0002-5293-8493
E-mail: leonel.bene@gmail.com
Recebida 29 maio 2020
Aceita 8 jun. 2020 Mestrando Leonel Elias Bene
Programa de Pós-Graduação em Educação
Universidade Federal do Amazonas (Brasil)
Universidade Púnguè - Extensão de Tete (Moçambique)
Linha de Pesquisa Educação, Políticas Públicas e Desenvolvimento Regional
Orcid id: https:/ / orcid.org/0000-0002-5293-8493
E-mail: leonel.bene@gmail.com
Recebida 29 maio 2020
Aceita 8 jun. 2020 Mestrando Leonel Elias Bene
Programa de Pós-Graduação em Educação
Universidade Federal do Amazonas (Brasil)
Universidade Púnguè - Extensão de Tete (Moçambique)
Linha de Pesquisa Educação, Políticas Públicas e Desenvolvimento Regional
Orcid id: https:/ / orcid.org/0000-0002-5293-8493
E-mail: leonel.bene@gmail.com
Recebida 29 maio 2020
Aceita 8 jun. 2020 